\title{
Szerkesztôségi közlemény
}

Lapunk alapító fószerkesztôjének, Kopp Máriának halálával e feladatkörre engem talált meg a sors.

A folyóirat nemes hagyományait szeretném folytatni változatlan célkitúzésekkel.

Tisztelettel köszöntöm lapunk minden olvasóját:

Túry Ferenc

fôszerkesztô 